\title{
Factors Contributing to Inefficient Management and Maintenance of Waqf Properties: A Literature Review
}

\author{
Farah Nadia Abas, Fauziah Raji* \\ Department of Land Administration, Faculty of Geoinformation and Real Estate, Universiti Teknologi Malaysia, Johor, \\ Malaysia \\ *Corresponding author: farah_nadia87@yahoo.com
}

\section{Article history}

Received: 2017-10-10 Received in revised form: 2018-01-15 Accepted: 2018-01-24 Published online: 2018-10-31

\begin{abstract}
Fundamentally, an effective management of properties has been established as a healthy way of increasing the value and benefits of real estate. The sources of awqaf (waqf) are quite rich. However, the issues of the sustainability of valuable waqf properties have not yet been explored especially with regards to sustaining and enhancing the value through sound principles of property management. Thus, this paper presents a literature review concerning the factors contributing to inefficient management and maintenance of waqf properties globally with a particular focus on Malaysia. From the findings, they have five factors identified that consist of; insufficient fund, lack of best performance by waqf manager, unregistered of waqf land under SIRC, out-dated data and confiscation of ownership rights by heirs from SIRC. Yet, due to the lack of study in the area of the maintenance function of waqf properties, it strongly suggested that there is a need to fill the gap in the body of knowledge of which both; management and maintenance function (operational management) shall take into account in waqf management practice as well. This is very important to achieve sustainability of valuable waqf properties by providing a continuous stream of income through effective and efficient of the waqf management system.

Keywords: Property Management, Inefficient Management and Maintenance, Waqf Properties, Sustainability, Income
\end{abstract}




\subsection{INTRODUCTION}

Waqf (pl;awqaf) as referred to traditionally Muslim philanthropy, is a form of perpetual, continuous and sustainable charity (sadaqah jarriyya), pious action or endowment, and benevolence instruments (Dahlia \& Haslindar, 2013; Kahf, 2003; Raissouni, 2001; Sadeq, 2002). Over the centuries, waqf plays a significant role in enhancing profit and social benefit to cater for larger needs of the Muslim society. In this regards, an attempts to strengthen waqf income should be made more extensively for an accomplishment of waqifs objective.

However, though the numbers of waqf properties are increasing exponentially in almost all Islamic countries, calls for more efficient of management for better value of waqf properties are very alarming. In fact, several researchers claimed that waqf properties which have high potential for income generation are seen lack of management and maintenance (Chowdhury, Ghazali, \& Ibrahim, 2011; Dahlia \& Haslindar, 2013; Majid \& Said, 2014; A. H. M. Noor, Ali, Abdullah, \& Tahir, 2014). As concurred by Saad, Kassim, and Hamid (2013), if those waqf properties are not maintained properly so their yield does not contribute largely to the benefit of society. Ahmed and Khan (1998) claimed that lack of basic maintenance of best waqf properties (having tremendous commercial potential) could affect the physical performance and may deteriorate as well.

In fact, waqf management in Malaysia also faced same problems in terms of the inefficiencies of the way the waqf properties were being managed, with the majority of the waqf properties not being fully utilized (A. H. M. Noor et al., 2014). As reported by Department of Awqaf Zakat and Hajj (JAWHAR) in 2015, waqf properties (land) in Malaysia has an estimated total value of RM4 billion (Norinah, Rahman, Ahmad, \& Mahdzan, 2015). Thus, the greatest challenge among the State Islamic Religious Council (SIRC) as the sole trustee of waqf properties is how they can ensure that waqf value is increased and allow the waqf institution to be financially sustainable.

Therefore, by applying a secondary method of research methodology, this paper is intended to provide a better understanding of the concept of property management and efficiency in management and maintenance of waqf properties. Then, this paper will discuss and highlight the factors contributing to inefficient management and maintenance of Waqf properties globally with a particular focus on Malaysia. Lastly, the recommendations by several researchers and the summary will be presented at the end of this paper.

\subsection{LITERATURE REVIEW}

\subsection{Waqf Governance in Malaysia}

Waqf is listed under the State List of the Federal Constitution 1957. Given that waqf is a state matter, it is within the exclusive powers of the state government to legislate laws on the administration of waqf. Since 1950, the provisions relating to waqf has been enshrined in the Respective States' Administration of Islamic Law Enactments. The first state law that contains a provision relating to waqf is preceded by Selangor in 1952 namely Administration of Muslim Law Enactment 1952, Selangor (Kader, 2016). All the Enactments in respective state declaring waqf as follows;

"Notwithstanding any provision to the contrary contained in any instrument or declaration, governing of affecting it' the State Islamic Religious Council is to be the 'sole trustee' of all waqf' 
These provisions would effectively give the power to SIRC as the sole trustee or Mutawwali in managing, maintaining, protecting and developing waqf either general or specific waqf. The next provision that vests the waqf properties on the Council as follows:

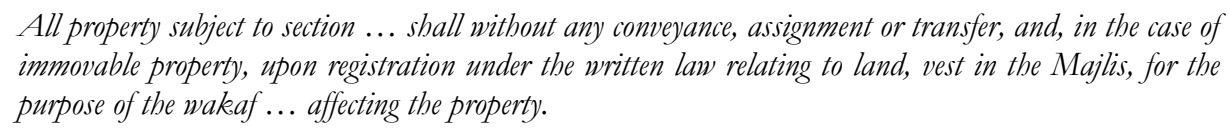

With such provisions, the jurisdiction of waqf properties is put under each SIRC as the sole trustee. Therefore, SIRCs could streamline and refine the clauses as stated in the Administration of Islamic Law Enactments by establishing the further rules and regulations. Currently, five states have been established the specific rules and regulation for waqf namely Johor Wakaf Rules 1983 and followed by the Selangor Wakaf Enactment 1999, Negeri Sembilan Wakaf Enactment 2005 and Malacca Wakaf Enactment 2005 (M. T. S. H. Mohammad, 2009). The new law established namely Perak Wakaf Enactment 2015.

According to S. A. Hassan and Rashid (2015); Mahamood (2006b); Siraj (2012), the main responsibilities of SIRC are of, (i) to ensure all waqf properties are being used, spend and utilised in accordance with the terms and conditions set out by waqif, (ii) to safeguard the waqf property through enforcement of law for administration and management, (iii) to develop the waqf property and (iv) to provide a report of the performance of waqf management. However, SIRC also has the right to appoint or give written permission to any party as the administrator or manager of the waqf and hold any property (mawquf) on his behalf as stated in Section 4, Selangor Wakaf Enactment 2015.

However, there are three characteristics of waqf should be catered by SIRC to carry out their responsibilities in managing and maintaining the waqf properties; irrevocability, perpetuity and inalienability. Once the waqf declaration has been done, the property made for waqf cannot be the subject of any sale, disposition, mortgage, gift, inheritance, attachment, or any alienation, that is inalienability. It effectively restricted the power of SIRC to manage the waqf. Moreover, in the sense of irrevocability, waqif has no power to cancel his donation. The waqif's heir also cannot take it by way of inheritance. It does mean that ownership remains in Allah. In the case of mismanagement, the waqif also cannot cancel the waqf. Harasani (2015) argued that the remedy shall not come by cancelling the waqf, but it must be remedied by making SIRC liable for his actions. In another context, perpetuity means that subject matter of the waqf should remain so forever. Its mean the usufructs from the waqf must continuously use by the beneficiaries as prescribed by the waqif. However, due to the multiplying of beneficiaries across generations could render waqf profits so low. Since the cost of management exceeds the profits gained, hence it becomes the challenge to SIRC to match the high cost with the prevailing needs of Ummah.

From the aforementioned, it is very challenging to SIRC as the waqf governance to manage the waqf properties while all the characteristics of waqf need to be encountered. It shows how differences waqf properties with the conventional properties. Therefore, SIRC should play the greater role as an efficient, skillful and professional administrator in managing, maintaining and preserving the perpetual concept of waqf properties without disregard the objective of waqf.

\subsection{The Concept of Property Management in Waqf Properties}

Property asset is a key resource for the estate owner or organizations that should be managed and controlled through an effective property management system. Property management can be defined as the act of operating the property with the aim of sustaining the capital value and 
income of the property in the line with the objective of the owner. Traditionally, property management involves various tasks concerning with managing the buildings, the collection of rents, payment of outgoings and maintenance, including repair and the provision of service. Christudason (2004) claimed that it should be carried out to maintain the building and thereby prolong its lifespan. As stated in the Valuers, Appraisers and Estate Agents Act 1981, Act 242, the functions of property management are not only entailed on management and maintenance aspect only but it could beyond than that. Malaysian Property Management Standards (MPMS) categorize the scope of property management into eight (8) roles namely; (i) building management, (ii) maintenance management, (iii) financial management, (iv) administrative management, (v) insurance management, (vi) health, safety and emergency, (vii) tenancy/ lease management and (viii) facility management shall take into account for management improvement.

Three main objectives of property management outlined by Richard (1961), (i) to optimize and maximize the property investment return and cost saving, (ii) to prolong and maintain the physical property and (iii) to increase capital value of the property in terms of investment. Additionally, Epley and Rabianski (1986), Loh (1991) and Thorncroft (1965) summarized that the focus for property management is the attainment of financial objectives in terms of rental income and investment return. On the other hand, Scarrett (1983) has argued that the function of property management is a mixture of the achievement of financial objectives and practical management as well which maintain investment and occupational value to achieve for short-term and long-term objectives.

Since waqf cannot be sold and used as collateral (M. T. S. Mohammad \& Mar-Iman, 2006), hence, the sources of finance of income generating waqf assets should focus on the waqf rental (usufruct) instead of capital gain. More importantly, the rental might be increased by adopting the best practices of property management. As such, the building must be well-functioned (Hin $\mathrm{Li}$, 1997). On the other hand, Oyedokun, Oletubo, and Adewusi (2014) claim that tenants' satisfaction is key to achieving maximization of real property investment returns. This is because the tenants are the main consumers of the commercial buildings, their role in property market affects greatly the contribution to property investment. Their contribution is reflected in rental growth, vacancy rate, lease execution, lease breaks, landlord-tenant disagreements and building reputation (RICS, 2005).

As the tenants are players to be tackled by the property manager, there is a need for quality service delivery (Dean \& Lee, 1998) and good maintenance (Appel-Meulenbroek, 2008; Baharum, Nawawi, \& Saat, 2009). Both of these factors could determine tenants' satisfaction. Oyedokun et al. (2014) argued that a good property management should focus on the needs of the tenants also rather than the physical buildings.

From the foregoing, it can be concluded that property management merely refers to operational management which their context broadly focus on two main tasks (i) the management, and (ii) the maintenance. This is consistent with the property management framework developed by (Baharum et al., 2009) in Figure 1. The management involves all the coordination work, supervision and other management tasks, also termed as a process, whereas, maintenance involves the outcome of the physical product which is property or building. It does reflect that waqf property management shall involve the duties to sustain and enhance the value as well as maximise the income generation of the waqf properties. Hence, in a way for revitalizing the waqf management system, one may need to study the both; management and maintenance function. 
Figure 1: The Framework of Property Management

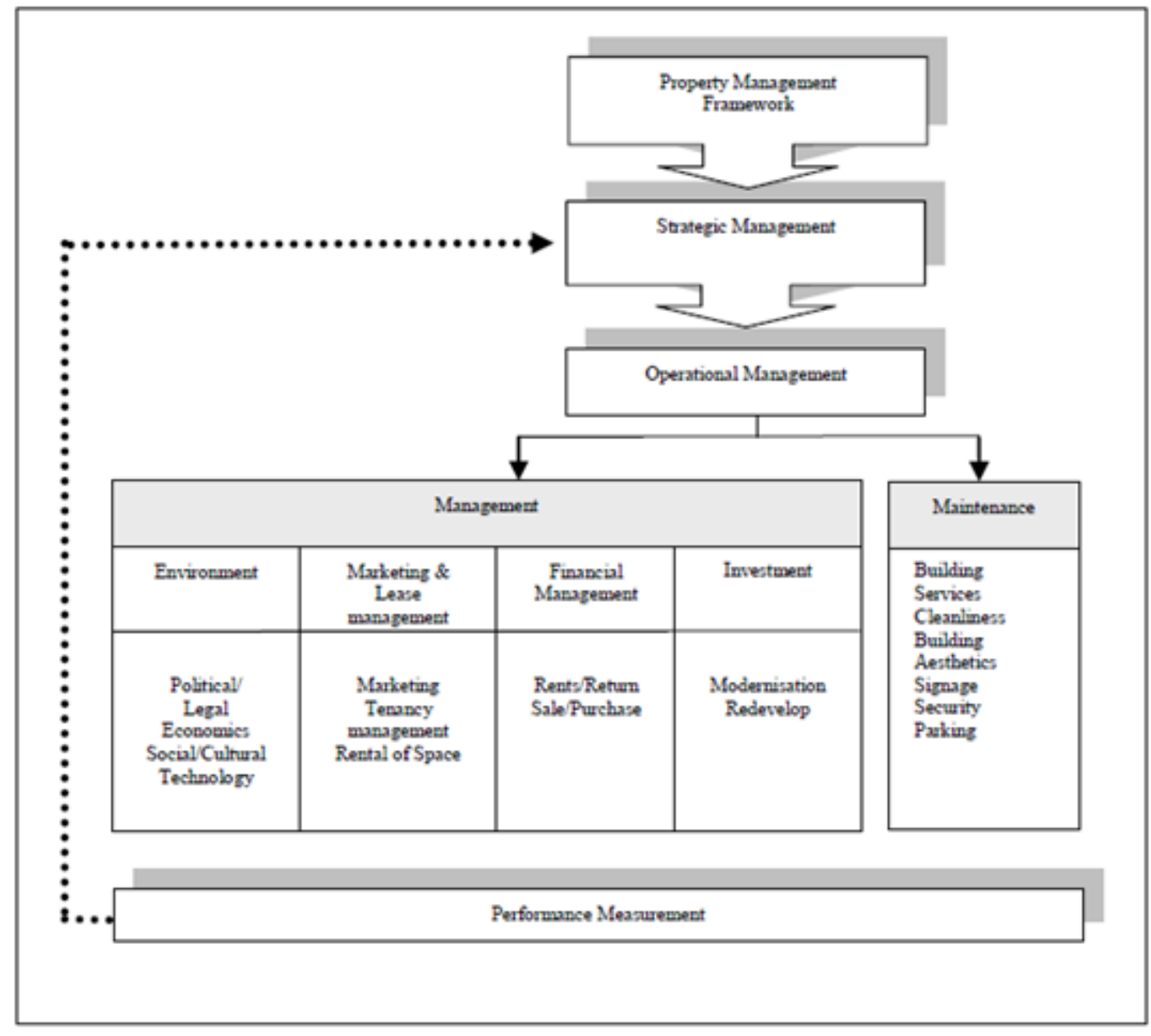

Sources: Adopted from (Baharum et al., 2009)

\subsection{The Need for Efficiency Management and Maintenance in Waqf Properties}

From an economic perspective, waqf management is defined as changing the usage of waqf properties, from consumption to production, so that the waqf properties can continue to generate returns in the future for the benefit of the waqf beneficiaries (Kahf, 1998). However, Ibrahim and Khan (2015) referred waqf management as to execute or control that property with a view to achieving some predetermined target with a very dexterous management. Thus, as the powers, duties and functions of waqf management in Malaysia are vested under SIRC as the sole trustee of waqf properties, M. T. S. H. Mohammad (2010) asserted that their scope of management shall include an upkeep, maintenance, dealings in it for keeping it productive; development, regeneration or redevelopment; development and regeneration finance. They also should be responsible for the investment of capital, management of its income and distributing to the beneficiaries.

The waqf properties will only be considered sustainable if their generated income can accomplish the waqf philosophy through the distribution of income for beneficiaries and the investment for building itself. Therefore, an effective management of waqf properties is the foremost attributes to attain which has been established as a healthy way of increasing the value 
and benefits of real estate (Karim, 2007; Kholid, Sukmana, \& Hassan, 2009). As stated by Karim (2007), an effective and efficient management of waqf could provide greater return and potential for the awqaf properties so as to maximize the social and religious benefits.

More importantly, it will certainly provide a return to the Malaysian economy (A. H. M. Noor et al., 2014), since the number waqf properties depict positive growth around the country. In fact, massive reduction in government expenditure which then will lead to a reduction in budget (deficit budget) that significantly improve the economic growth of our country (Sedek, Yaakub, Hamid, \& Palil, 2013). A macroeconomic problem such as poverty and unemployment rate could also be addressed if we have a good waqf management system. Therefore, SIRC as the sole trustee needs to be proactive and innovative so as to ensure waqf properties could be managed efficiently by generating substantial revenue for the widened Muslim community (Rani \& Aziz, 2010).

Moreover, by estimating the physical building can be in a good shape in 60 years (Dunn, 2010), hence, a waqf properties are no exception to preserve its physical life as well. In fact, the requisition of repairs of waqf properties has been expressed literally by researchers. As such, according to Ahmad (1938) and Al-Sharbini (1958) specified that the income from waqf properties must be firstly attended with expenses for continual repairs. Then, Al-Marghinani's (1936) supported that the repairs must first be made by the right person from time to time. This could be implied that such as qualified and professional manager should go through over the process. Therefore, whether the waqif has been stipulated in waqf deed or not, on what expenses should it be spent from the income, the highest priority is for maintenance (Ghazaleh, 2011; Othman, 1982).

\subsection{Factors Contributing To Inefficient Management and Maintenance of Waqf Properties}

The development of waqf properties is growing extensively over the years in tandem with the prevailing needs of society around the Muslim country. However, most of the waqf properties which have tremendous commercial potential are lacking sound principles of property management that subsequently hindering the maximization of real estate investment returns (A. Hassan \& Shahid, 2010). Thus, by focusing on the spectrum of property management, the causal consequences relating to inefficiency of waqf management and maintenance need to be investigated as follows;

\subsubsection{Insufficient Fund}

One of the major problems is lack of funds for maintaining and managing waqf properties including operational costs (M. Abdullah, 2010; Chowdhury et al., 2011). It was supported by the notion A. H. M. Noor et al. (2014), Osman, Mat, Ahmad, and Othman (2015), Aminah Mohsin and Mohammad (2015) and A. Hassan and Shahid (2010) that waqf management suffered from financial shortage. Even though the Federal Government has allocated about RM 256.4 million through the $9^{\text {th }}$ Malaysian Plan (RMK-9) for waqf projects (Zakaria, Hassan, \& Latiff, 2014) and RM 1.9 billion in $10^{\text {th }}$ Malaysian Plan (RMK-10) (Bernama, 2010), but all these grants focus on waqf development only. Certainly, the cost for further improvement of waqf properties from the government budget is always questionable and remain unclear since is not sufficient at all (Samsudin, 2017).

In addition, most of the waqf projects funded by the government are not only for the social contribution, but it could be financially sustained waqf properties as well (F. M. Noor, 2011). 
However, this is possible if waqf properties can generate the stream of income through leasing of the income-producing commercial. Basically, the income generated may subject to different purposes specified by the waqif ie; i) distribution to beneficiaries, ii) providing maintenance cost for another public waqf; school, mosque, hospital and iii) surplus from the income after all expenses had been deducted will be channelled for a benefit the forthcoming waqf properties.

Since the sources of income merely focuses on the waqf rental (usufruct), nonetheless, it is discovered that rental accumulation of waqf properties remain low (Ali et al., 2016; Majid \& Said, 2014; Aminah Mohsin \& Mohammad, 2011; Ngah, 1992; Rani, Ismail, \& Ismail, 2010). This notable issue is caused by the method of how is the waqf properties being managed and not fully utilized in a proper investment (M. Abdullah, 2010) and (Chowdhury et al., 2011). As stated by Ismail, Salim, and Hanafiah (2015), failure to lease out the land at a competitive rate and failure to systematically collect rent arrears from the tenants could be the foremost attributes for lower rental accumulation. The tenant failed to pay their rent consistently although the rental fees are lower from the market level. Moreover, some of the tenants rent the premise without permission from the SRICs as the sole trustee. They just make an agreement with the Management of Mosque as reported by (Jabatan Audit Negara Malaysia, 2014). Thus, all indicators aforementioned will reduce the availability of operational cost instead of distribution for beneficiaries as main waqif's objective only.

\subsubsection{Lack of Best Performance by Waqf Manager}

As stated by Chowdhury et al. (2011), the successful management of waqf properties is solely dependent on their administrators itself. However, another problem occurred in most SIRCs is the lack of best performance of appointed waqf manager. Waqf management systems are found difficult to undertake as it is caused by limited personnel and not having staff who are truly skilled (Puad, Rafdi, \& Shahar, 2014), less expertise (Abdul Malik, 2012; Harun, Isa, \& Ali, 2012) and experienced in this field (S. Abdullah, Abdul Razak, \& Hamid Kadir Pakir, 2011), lack of qualified manpower (Dahlia \& Haslindar, 2013; Mahamood, 2006a; Md, Iftekhar, Muhammad, \& Yasoa, 2012). Kamaruddin (1992) acknowledges that most of the officers and their subordinates in charge of waqf land have no or little experience and knowledge about property management. Moreover, there are some involvements by the non-Muslims in managing the waqf properties (Dahlia \& Haslindar, 2013). Huzaim (2014) claimed that non-Muslim cannot be in charge of a waqf according to the Fuqaha' because the waqf is an Islamic concept and non-Muslim cannot carry out the duties concerning it.

In fact, since 1936, the requisition of appointment of qualified and professional manager of waqf assets has been expressed literally by Al-Marghinani's (1936). He contended that repairs must be carried out by the right person from time to time. As the continuous performance of waqf highly depends on efficiency in waqf management system, thus SIRC as the sole trustee, mutawwali, waqf manager must be professional, knowledgeable and well trained (M. T. S. Mohammad \& Iman, 2005) in the Islamic principles and the laws governing them. Moreover, they must understand Islam in a true sense and succeed in internalizing the Islamic concept in performing their duties as mutawalli, as they believe that they are not only accountable to the waqif but most importantly to Allah (A. H. M. Noor et al., 2014).

Sedek et al. (2013) further elaborated that the qualifications of the Mutawalli refer to the ability, willingness and beliefs in utilizing waqf assets with trust and reliance. Huzaim (2014) deduced that the caretaker of waqf properties is an individual who has to be selected carefully and he should have the characteristics of sincerity, honesty and faithfulness because he will be doing charity work and serving people in need in most cases. 


\subsubsection{Unregistered Of Waqf Land Under Sirc}

As the sole trustee of waqf properties and the registered owner of the waqf land, SRICs are empowered by law to actively manage and use waqf properties to generate income through yields and rentals (Hanefah et al., 2011). Hence, in order to carry out their rights as waqf manager legally, the ownership of indefeasible title (NLC, 1965) is needed. However, the number of unregistered waqf land increased year by year in most of the SIRCs (Auditor General Report 2014, Series 3). In fact, SIRCs are having a problem in claiming the right as sole trustee for that waqf.

The cases mostly relate to registration of waqf properties involved; (i) there are a lot of waqf land which is still registered under individuals, mosque committee or qariah or even the endowers themselves, (ii) delay in registration process; either in the stage of registration at Land Office or it is subjected to the approval by State Authority and (iii) donor's heir refuses to acknowledge the waqf and decides to distribute the property according to estate distribution (Mohamad, Kader, Zubaidah, \& Ali, 2012).

Hence, by having an unclear status of ownership lead to the issue in the right of the custodian of Waqf properties. In addition, SIRCs may not carry out their waqf management functions legally until the indefeasible title vested under SIRC. This is another issue that should be highlighted in accordance with law by providing a clear procedure of registration under SIRC and NLC.

\subsubsection{Outdated Data}

For effective and efficient management, the need of information by users ie; management team is high towards SIRC's annual report includes of non-financial information instead of financial information (Masruki, Hussainey, \& Aly, 2016). These include background, strategic and fiduciary information, performance and activities and importantly, how efficiently the distribution of funds is carried out (Khumawala, Parsons, \& Gordon, 2005; Van Der Heijden, 2013; Wahab \& Rahman, 2015).

Of importance, to provide a good report, the data recording in waqf management system shall be updated all the time. Thus, there is a need to do a comprehensive survey of waqf as a pre-requisite for effective waqf management. This systematic action will prevent and protect waqf properties from being encroached, occupied illegally or leased to the non-Muslims (Ismail et al., 2015). Most crucially, as reported by Auditor General Report of 2014 Series 3, most of the SIRCs fail to broadcast the proclamation for all of their waqf lands. There is a case in MAIM whereby a proclamation as stated under Section 83, Waqf (State of Malacca) Enactment 2002, is none due to the lack of awareness about the requisition of the proclamation of all their waqf land. It is pertinent to do so to avoid from an encroachment and to provide a better service for updating data and monitoring all their waqf properties (R. A. Rashid, Hussin, \& Yaakub, 2015).

Therefore, the record of waqf land needs to be updated with complete and orderly information, as well as to provide a systematic online database to be easily reached by the waqf management and waqif as well. This is to enable them to review the records, update information, and check the status of endowment for each land, broadcasting of the proclamation and the recommendation of the audit. 


\subsubsection{Confiscation of Ownership Rights by Heirs from Sirc}

Due to the absence of specific provisions relating to waqf management in State Waqf Enactment, it is found that they will provide lack of understanding on waqf land management procedures, dos and don'ts among the waqif and their heirs. Some of the cases, neither waqif nor their heirs not being provided with clear procedures for registration involving a Memorandum of Transfer (MOT) as reported by Auditor General Report 2014, Series 3. In doing so, the heirs of the waqif tend to breach the contract in the management of waqf properties. As a consequence, the heirs of waqif tend to confiscate the land once the waqif died as they claimed the waqf land as its rightful inheritance.

Another case prevailed where there are waqf deeds which are blurred and illegal (Mokhtar, Ibrahim, Omer, \& Osman, 2008). This waqf deeds are deemed as illegal if it does not comply with the legal condition including of; (i) land title (must register as waqf), (ii) founders condition (has to respected), (iii) beneficiaries (rights have to be met) and (iv) perpetuity of the waqf (has to be ensured). This situation also allowed the heirs of the waqif to claim the land in the court. Therefore, there are many unresolved court cases between trustees and family members may take a longer time to settle and finally might contribute to the ignorance of management and maintenance of those waqf assets.

Therefore, based on previous contributors identified, the indicators for inefficient waqf management and maintenance is summarised in Figure 2 as follows;

Figure 2: Indicators for Inefficient Waqf Management and Maintenance

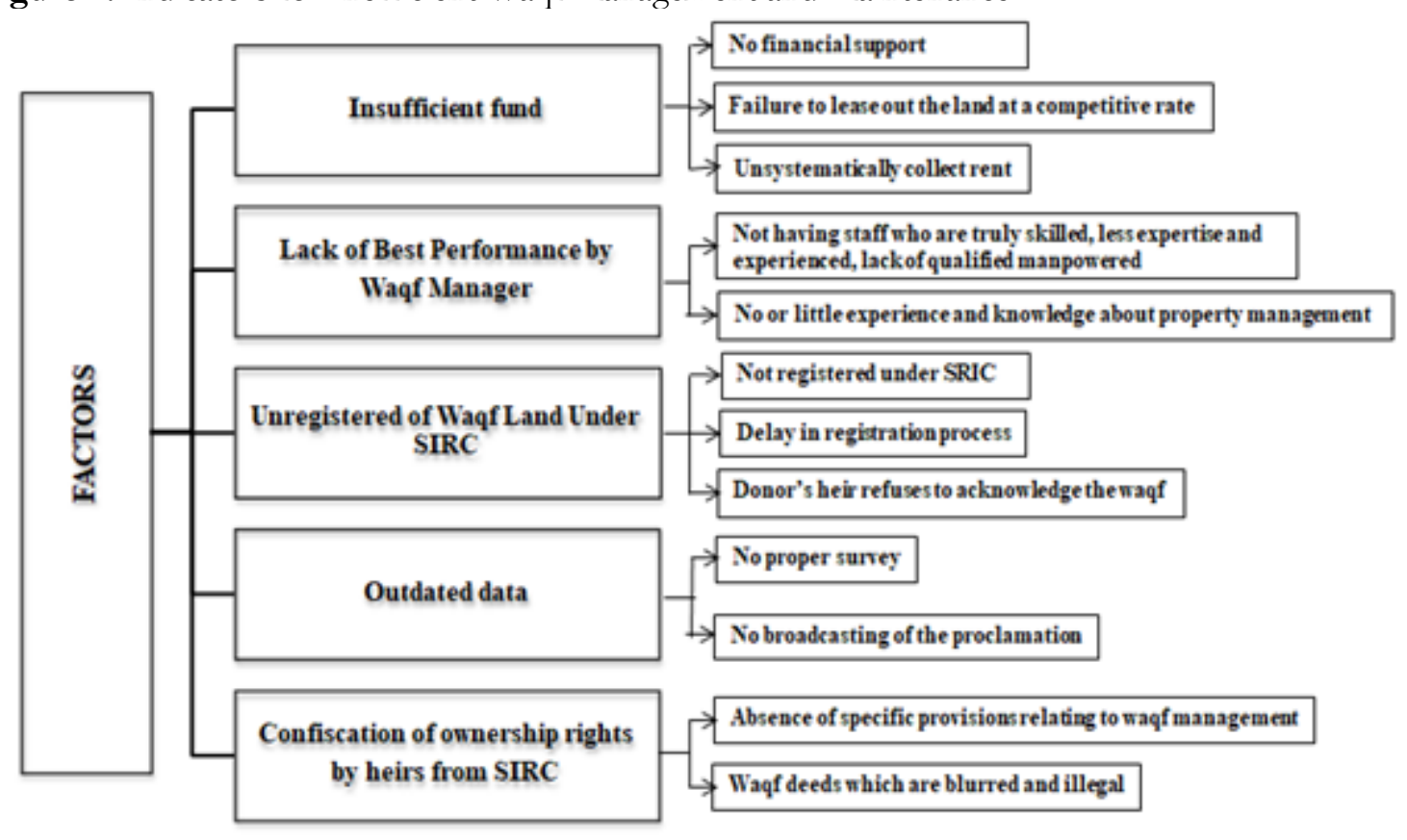

Sources: Developed by Authors (2017)

Then, based on Auditor General Report 2014, Series 3 has revealed that there are six (6) SIRCs which are confronted with the above issues and tabulated as follows; 

pp. 53-67

\begin{tabular}{|c|c|c|c|c|}
\hline Contributors & $\begin{array}{c}\text { Delay in } \\
\text { registration }\end{array}$ & $\begin{array}{c}\text { Unclear of } \\
\text { Waqf } \\
\text { procedures } \\
\text { and MOT }\end{array}$ & Outdated data & $\begin{array}{c}\text { No broadcasting } \\
\text { of proclamation }\end{array}$ \\
\hline SIRC & & & $\mathrm{X}$ & $\mathrm{X}$ \\
\hline MAIK & $\mathrm{X}$ & & $\mathrm{X}$ & $\mathrm{X}$ \\
\hline MAIS & & & $\mathrm{X}$ \\
\hline MAIM & $\mathrm{X}$ & & $\mathrm{X}$ & $\mathrm{X}$ \\
\hline MUIP & & $\mathrm{X}$ & $\mathrm{X}$ & \\
\hline MUIS & & & & \\
\hline
\end{tabular}

*MOT: Memorandum of Transfer

Sources: Auditor General Report 2014, Series 3

\subsection{RECOMMENDATION AND DISCUSSION}

In retrospect, several researchers have made the recommendations for the improved management and maintenance of Waqf properties as tabulated in Table 2.

Table 2: The Recommendations for Inefficient Waqf Management and Maintenance

\begin{tabular}{|c|c|c|c|}
\hline No. & Contributors & Researchers & Recommendation \\
\hline \multirow[t]{6}{*}{1.} & \multirow[t]{6}{*}{ Insufficient fund } & (Ismail et al., 2015) & $\begin{array}{l}\text { Waqf land rental rate should be increased to } \\
\text { commensurate with the current rental rate and } \\
\text { more staff should also be hired to ensure that the } \\
\text { rent is collected on time and the records of waqf } \\
\text { land and tenants must be systematically kept and } \\
\text { frequently updated. }\end{array}$ \\
\hline & & (Osman et al., 2015) & $\begin{array}{l}\text { The application of Islamic concept of Hibah } \\
\text { Mudarabah in implementing waqf management } \\
\text { strategy as a wealth redistribution mechanism } \\
\text { instead of the present welfare mechanism role. }\end{array}$ \\
\hline & & $\begin{array}{c}\text { (Dahlia \& Haslindar, } \\
\text { 2013) }\end{array}$ & $\begin{array}{l}\text { Corporate waqf gives new meaning in generating } \\
\text { income to improve the economy of the Ummah. } \\
\text { It is expected that all issues pertaining to waqf } \\
\text { management such as management negligence, } \\
\text { flaws and ineffectiveness can be solved through } \\
\text { corporate waqf. }\end{array}$ \\
\hline & & (Kholid et al., 2009) & $\begin{array}{l}\text { By proposing a generic model that depicts the } \\
\text { significant role of Sukuk Al-intifa'a as the } \\
\text { financial instrument in empowering waqf } \\
\text { performance. The concepts of the primary } \\
\text { project (target project) will be finance by the } \\
\text { waqf administration by raising cash waqf while } \\
\text { secondary projects aim for generating cash flow } \\
\text { to finance the regular operational expenses of the } \\
\text { target projects. }\end{array}$ \\
\hline & & (Mokhtar et al., 2008) & $\begin{array}{l}\text { The council constantly relies on investment or } \\
\text { loans from a trusted institution that is allowed by } \\
\text { the Shariah. }\end{array}$ \\
\hline & & (Ramli, 2005) & $\begin{array}{l}\text { Sources of funds should be established in order } \\
\text { to maintain and improve the management of } \\
\text { waqf existing and future through cash waqf or } \\
\text { issuance of Sukuk Musyarakah. }\end{array}$ \\
\hline 2. & $\begin{array}{l}\text { Lack of Best } \\
\text { Performance by Waqf } \\
\text { Manager }\end{array}$ & (Puad et al., 2014) & $\begin{array}{l}\text { Recruiting professionals such as civil engineers, } \\
\text { architect and quantity surveyor as part of their } \\
\text { team may facilitate MAIS to manage the portfolio } \\
\text { professionally and capable of managing the } \\
\text { modern contemporary knowledge as well. }\end{array}$ \\
\hline
\end{tabular}




\begin{tabular}{|c|c|c|c|}
\hline \\
\hline & & (Md et al., 2012) & $\begin{array}{l}\text { Waqf should be managed with qualified, } \\
\text { knowledgeable and professional managers who } \\
\text { are well acquainted with Islamic as well as } \\
\text { country laws to make right symbiosis for } \\
\text { attaining the performance goals in the Waqf } \\
\text { systems. }\end{array}$ \\
\hline & & $\begin{array}{l}\text { (Chowdhury et al., } \\
\text { 2011) }\end{array}$ & $\begin{array}{l}\text { Waqf properties should be managed solely by } \\
\text { qualified Muslims as to ensure that the objectives } \\
\text { of the waqf system are upheld. }\end{array}$ \\
\hline 3. & $\begin{array}{l}\text { Unregistered of Waqf } \\
\text { Land Under SIRC }\end{array}$ & (Mohamad et al., 2012) & $\begin{array}{l}\text { Enforcement of the registration of all waqf land } \\
\text { or other landed properties in order to protect and } \\
\text { manage the waqf properties efficiently. } \\
\text { The recording system of waqf land as practiced in } \\
\text { the land office must be improved to materialize } \\
\text { the expectation of the ummah and Islamic } \\
\text { principles on waqf. }\end{array}$ \\
\hline \multirow[t]{4}{*}{4.} & \multirow[t]{4}{*}{ Outdated data } & (Ismail et al., 2015) & $\begin{array}{c}\text { Systematic and efficient database of registered } \\
\text { land should be created and managed by skilful IT } \\
\text { personnel. }\end{array}$ \\
\hline & & (Bakhoum, 2014) & $\begin{array}{l}\text { Making an inventory of all waqf asset owned by } \\
\text { the institution that would include various } \\
\text { information such as the typology, date of } \\
\text { construction, state of conservation, etc.; the } \\
\text { URHC--GIS system should be used as a base for } \\
\text { future inventories as well as future interventions } \\
\text { (such as restoration, maintenance, etc.) to manage } \\
\text { the waqf asset efficiently. }\end{array}$ \\
\hline & & (S. K. Rashid, 2011) & $\begin{array}{l}\text { Survey of waqf properties by preparing a data- } \\
\text { bank of awqaf to know details of the number, } \\
\text { valuations, incomes, objects, expenditures, etc. of } \\
\text { every waqf property to devise an effective } \\
\text { administrative policy. } \\
\text { Full data of awqaf is a pre-requisite for effective } \\
\text { management and for this survey must be done in } \\
\text { all the countries where it has yet not done. }\end{array}$ \\
\hline & & (Mokhtar et al., 2008) & $\begin{array}{l}\text { There are several SIRCs such as Johor, Penang } \\
\text { and Kuala Lumpur that has a competent system } \\
\text { for restoring the data. One of the famous data } \\
\text { storing systems is Geographical Information } \\
\text { System which allows the waqf land to be } \\
\text { displayed on a location map with the attributes }\end{array}$ \\
\hline \multirow[t]{2}{*}{5.} & \multirow{2}{*}{$\begin{array}{l}\text { Confiscation of } \\
\text { ownership rights by } \\
\text { heirs from SIRC }\end{array}$} & (Samsudin, 2017) & $\begin{array}{l}\text { The information has to be instilled for the } \\
\text { community to have a full understanding on waqf. }\end{array}$ \\
\hline & & $\begin{array}{l}\text { (Che Zuina Ismail, } \\
\text { Syafini, \& Hanafiah, } \\
\text { 2014) }\end{array}$ & $\begin{array}{l}\text { SIRC has to confront with heirs who tried to } \\
\text { repossess the waqf wealth. }\end{array}$ \\
\hline
\end{tabular}

Sources: Developed by Authors (2017)

Based on Table 2, in order to address the problem of insufficient fund, highly depending on external sources of the fund instead of the self-income generated will limit the achievement of financial sustainability of waqf properties. The sources of waqf properties are quite rich which include land and building thereon. If it can be commercialized into a profitable investment by having a good cash flow, it will allow the waqf institution to be financially sustainable until it no longer required financial support from external sources.

Moreover, a qualified, knowledgeable and professional waqf manager in regards to Islamic principles and property management should be appointed to ensure the achievement of waqf philosophy. Therefore, the attributes of a waqf manager (trustee) based on waqf needs and Shariah compliance should be clear enough. 
Next, the enforcement of waqf law regarding the registration and recording system under NLC need to be more proactive at all level including SIRC, Land Office, Department of Survey and Mapping and Department of Lands and Mines and State Authority to prevent from any disputed of rights especially by heirs in future. Other than that, a clear information, guidelines and rules of waqf procedure need to be clear enough among waqif and their heirs in order to secure a waqf status. Last but not least, an up to date and available data on waqf assets must also be provided and easy to be accessed at all time when it is needed.

From this literature, it could be implied that the waqf management system will be more efficient and effective by adopting the sound principles of property management. However, it is found that there is a lack of study by researchers in emphasizing the maintenance function of waqf properties. By considering both; management and maintenance function (operational management) in waqf management practice, it could provide a continuous stream of income and maximise the waqf value. That is the way of the waqf properties can be sustained by having a good capability of property management while the waqf philosophy remains achievable.

\subsection{CONCLUSION}

This paper presents the issues of management and maintenance of waqf properties that should be addressed especially by the waqf institutions. It can be suggested that the concept of property management should be adopted to ensure that the value of waqf properties could be well sustained and enhanced. However, it's subjected to further study in regards to the best practice of property management. Of importance, those waqf properties could generate a better income for the prevailing needs of Muslims largely and can assist greatly in the economic development of the Muslims. Hence, it will lead waqf institutions to be a financially sustainable instead of much relies on the external fund. Therefore, SIRC as the sole trustee should play the greater role as an efficient, skillful and professional administrator in managing, maintaining and preserving the perpetual concept of waqf properties to achieve waqf philosophy.

\section{Acknowledgement}

The authors are grateful to the Ministry of Higher Education and Universiti Teknologi Malaysia for their generous grant to support this work..

\section{References}

Abdul Malik, A. B. (2012). Comparative Study On Management Of Waqf Land. Degree Dissertation, Universiti Teknologi MARA, Malaysia.

Abdullah, M. (2010). "Malaysia needs transformation of Waqf management". Travelodge PhD Wakaf@ Mohamad Salleh Abdullah, blog entry, retrived from: https:// sallehabdullah.blogspot.com/search?q=Malaysia + needs+transformation +of +Waqf +mana gement, date of accessed 27th February 2018.

Abdullah, S., Abdul Razak, A., \& Hamid Kadir Pakir, A. (2011). "The characteristics of real estate assets management practice in the Malaysian Federal Government". Journal of Corporate Real Estate, Vol. 13(1), pp. 16-35.

Ahmed, H., \& Khan, A. (1998). "Strategies to develop waqf administration in India". Research paper (50).

Al-Marghinani's. (1936). Al-Hidayah. 4 vols. Cairo, .

Ali, S. N. M., Johari, N., Fauzi, N. S., Ahmad, N., Chuweni, N. N., \& Noor, A. H. M. (2016). Income Optimization From Waqf Properties: Sustaining The Acheen Street Mosque. e-Proceeding of the Social Sciences Research ICSSR. 
Appel-Meulenbroek, R. (2008). "Managing 'keep' factors of office tenants to raise satisfaction and loyalty". Property Management, 26 (1), pp. 43-55.

Baharum, Z. A., Nawawi, A. H., \& Saat, Z. M. (2009). "Service Quality and Property Management Service: A Conceptual Framework". Journal of Built Environment, 6(1), pp. 12-34.

Bakhoum, D. (2014). Awqaf Properties; Maintenance and Management. Urban Regeneration Project for Historic Cairo.

Chowdhury, M. S. R., Ghazali, M. F., \& Ibrahim, M. F. (2011). "Economics of Cash WAQF management in Malaysia: A proposed Cash WAQF model for practitioners and future researchers". African Journal of Business Management, 5(30), 12155.

Christudason, A. (2004). "Common property in strata titled developments in Singapore: common misconceptions". Property Management, 22(1), 14-28.

Dahlia, I., \& Haslindar, I. (2013). Revival of Waqf properties in Malaysia. Paper presented at the The 5th Islamic Economics System Conference (iECONS 2013), Kuala Lumpur, 4 - 5 September 2013.

Dean, D., \& Lee, C. (1998). "Winning applause". Journal of Property Management, 63(2), 42-46.

Dunn, C. (2010). "The Appraisal Of Real Estate 3rd Canadian Edition Busi 330". Review Notes by Real Estate Division and Chuck Dunn.

Epley, D. R., \& Rabianski, J. (1986). Principles of real estate decisions: Reston Pub Co.

Harun, R., Isa, Z. M., \& Ali, N. (2012). Preliminary findings on Waqf management practices among Selected Muslim Countries. Paper presented at the International Conference on Economics Marketing and Management IPEDR, Singapore, 26th to 28th February 2012.

Hassan, A., \& Shahid, M. M. A. (2010). Management and development of the awqaf assets. Paper presented at the Seventh International Conference-The Tawhidi Epistemology: Zakat and Waqf Economy, Bangi, 6-7 Januari, 2010.

Hassan, S. A., \& Rashid, R. A. (2015). Towards Improvement of The Rights And Duties of Mutawalli And Nazir In The Management And Administration of Waqf Assets. The 9th ISDEV International Islamic Development Management Conference : IDMAC2015 : Islamic asset management : PROCEEDING, 8 - 9 December 2015.

Hin Li, L. (1997). "Property management in China: opportunities and problems". Property Management, 15(1), 6-11.

Huzaim, Y. O. A. (2014). An Exceptional Woman Wife of a King: Darussalam Publishers.

Ibrahim, A. A. M., \& Khan, S. H. (2015). Waqf Management In Bangladesh: An Analysis From Maqasid Al-Shar 'Ah Perspective. Retrieved from iais.org.my on October 23, 2016

Ismail, C. Z., Salim, N. J., \& Hanafiah, N. J. A. (2015). Administration and Management of Waqf Land in Malaysia: Issues and Solutions" Mediterranean Journal of Social Sciences, 6(4), pp. 613.

Kader, S. Z. S. A. (2016). Kerangka Undang-Undang Pengurusan Wakaf Di Malaysia: Ke Arah Keseragaman Undang-Undang. Kanun, 28(1), pp. 101-126.

Kahf, M. (2003). The role of waqf in improving the ummah welfare. Paper presented at the International seminar on Waqf as a Private Legal Body, Islamic University of North Sumatra, Indonesia, 6-7 January, 2003.

Kamaruddin, N. (1992). Isu pembangunan tanah wakaf di Malaysia. Kuala Lumpur: Dewan Bahasa dan Pustaka (1st ed.).

Karim, S. A. (2007). Contemporary Waqf Administration and Development in Singapore-Challenges and Prospects. Paper presented at the Singapore International Waqf Conference 2007, 6 - 7 March 2007.

Kholid, M., Sukmana, R., \& Hassan, K. A. K. (2009). "Waqf Management through Sukuk Al-intifa'a: A Generic Model", Refereed Biannual Journal Spscialized in Waqf and Charitable activities, No.17-Year 9 (Kuwait Awqaf Public Foundation Studies and External Relations Department).

Loh, S. C. (1991). Property management: an overview. Surveyor, No. 4th Quarterly'91, pp. 25-32.

Mahamood, S. M. (2006a). Perundangan Wakaf dan Isu-isu Berbangkit. Konvensyen Wakaf Kebangsaan 2006, Kuala Lumpur, 12-14 September 2006. 
Mahamood, S. M. (2006b). Waqf in Malaysia: Legal and administrative perspectives: University of Malaya Press.

Majid, R. A., \& Said, R. (2014). Permasalahan Pengurusan Hartanah Wakaf Di Malaysia. International Surveying Research Journal (ISrJ), 4(1), 29-43.

Md, S. R. C., Iftekhar, A. C., Muhammad, M. Z., \& Yasoa, M. R. (2012). Problems of WAQF administration and proposals for improvement: A study in Malaysia. Journal of Internet Banking and Commerce, 17(1), 1.

Mohamad, N. A., Kader, S. A., Zubaidah, S., \& Ali, Z. (2012). Waqf lands and challenges from the legal perspectives in Malaysia. Retrieved from irep.iium.edu.my/28025/1/6a.pdf, date of accessed: September 22, 2017

Mohammad, M. T. S., \& Iman, A. H. M. (2005). An ideal financial mechanism for the development of waqf properties in Malaysia. Research reported available online: eprints, Universiti Teknologi Malaysia.

Mohammad, M. T. S., \& Mar-Iman, A. (2006). Obstacles of the current concept of waqf to the development of waqf properties and the recommended alternative. Malaysian Journal of Real Estate, 1(1), pp. 27-38.

Mohammad, M. T. S. H. (2009). A Proposal for a New Comprehensive Waqf Law in Malaysia. Retrieved from https://kantakji.com/wakf/a-proposal-for-a-new-comprehensive-waqf-law-in-malaysia.aspx, date of accesede: 29 October, 2016.

Mohsin, A., \& Mohammad, M. (2011). Weaknesses of current capital raising, financing, and investment methods of awqaf (Islamic Trusts). Paper presented at the International Conference on Social Science and Humanity, Singapore, 2011-02-26.

Mohsin, A., \& Mohammad, M. T. S. (2015). "The Effectiveness of Saham Waqf on Adequacy of Funds for Development Projects in Malaysia". International Journal of Real Estate Studies, Volume 9 Number 2.

Mokhtar, S., Ibrahim, M., Omer, S., \& Osman, D. H. J. H. (2008). Issues, Problems and Strategies of Waqf Land Development in Malaysia-Literature Review. Paper presented at the 7th Annual Conference Management in Construction Researchers' Association MICRA, Kuala Lumpur, 8 - 19 June 2008.

Ngah, K. (1992). Isu pembangunan tanah wakaf: Dewan Bahasa dan Pustaka, Kementerian Pendidikan, Malaysia.

Noor, A. H. M., Ali, N. A. M., Abdullah, A., \& Tahir, H. H. M. (2014). The Waqf Governance Framework in Malaysia. International Conference On Development Of Social Enterprise And Social Business For Eradication Of Extreme Poverty And Street Begging, Chittagong, Bangladesh, 19-20 December 2014.

Noor, F. M. (2011). Wakaf Delivering System in Malaysia with Special Reference to Jabatan Wakaf, Zakat dan Hai (JAWHAR) dan Yayasan Wakaf Malaysia. . 3rd Langkawi International Conference on Islamic Finance and Economics (LIFE3), Langkawi, 29 - 31 October 2011.

Norinah, M. A., Rahman, M., Ahmad, R., \& Mahdzan, N. S. A. (2015). Necessity of effective and efficient business model for development of Waqf lands in Malaysia. Conference: Muktamar Waqf IQLIMI II 2015: Enhancing social enterprise and Islamic philanthropy through Ijtima'i and Waqf, At USIM, 26 August 2015.

Osman, S., Mat, I., Ahmad, J., \& Othman, Y. (2015). "Unlocking Value Of Waqf Property Using Hibah Mudharabah: A Case Study Of Commercial Buildings In Kedah, Malaysia". International Journal of Development Research, 5(5), pp. 4294-4299.

Oyedokun, T., Oletubo, A., \& Adewusi, A. (2014). "Satisfaction of occupiers with management of rented commercial properties in Nigeria: An empirical study". Property Management, 32(4), pp 284-294.

Puad, N. A. M., Rafdi, N. J., \& Shahar, W. S. S. (2014). Issues And Challenges Of Waqf Instrument: A Case Study In Mais. E-proceedings of the Conference on Management and Muamalah (CoMM 2014).

Raissouni, A. (2001). "Islamic 'Waqf Endowment': Scope and implications", (A. Benhallam, Trans.). Rabat: Islamic Educational, Scientific, and Cultural Organisation, ISESCO.

Ramli, A. H. (2005). Pengurusan Wakaf Di Malaysia: Cabaran Dan Masa Depan. Pusat Penerbitan Universiti (UPENA) UiTM, Shah Alam Selangor. 
Rani, M. A. M., Ismail, H., \& Ismail, C. Z. (2010). Penyewaan Tanah Wakaf Dari Perspektif Hukum Syarak Dan Amalannya Di Malaysia. Kertas Kerja Seminar Syariah dan Undang-undang, Anjuran Universiti Sains Islam Malaysia (USIM), 2-3 November 2010.

Rashid, R. A., Hussin, R., \& Yaakub, N. I. (2015). Kawalan, Penguatkuasaan, Pendakwaan Serta Hukuman Bagi Isu Pencerobohan Tanah Wakaf Di Malaysia. in 9th ISDEV International Islamic Development Management Conference, Penang, 8 - 9 December 2015.

Rashid, S. K. (2011). Certain Legal and Administrative Measures for the Revival and better management of Awqaf. Islamic Research and Training Institute.

Richard, E. (1961). Property Management. cited in S.N. Kamaruzzaman, D. M.Tabir, A.M.A. Zaidi (2009): A Review of Managing Agent in Property Management Industry in Malaysia. Date of accessed July 25, 2016.

RICS. (2005). Royal Institution of Chartered Surveyors.

Saad, N. M., Kassim, S., \& Hamid, Z. (2013). "Involvement of corporate entities in Waqaf management: experiences of Malaysia and Singapore". Asian Economic and Financial Review, 3(6), pp. 736.

Sadeq, A. H. M. (2002). "Waqf, perpetual charity and poverty alleviation". International Journal of Social Economics, 29(1/2), pp. 135-151.

Samsudin, K. J. (2017). "Strengthening Education Waqf Fund For Higher Education Institutions". Contemporary Issues and Development in Islamic Social Finance, pp. 211-225.

Scarrett, D. (1983). Pengurusan Harta. Translation - Ismail Omar (1993). Kuala Lumpur: Dewan Bahasa dan Pustaka.

Sedek, A. S., Yaakub, N. I., Hamid, M. A., \& Palil, R. (2013). Waqf: A Contribution Towards Economic Development. Paper presented at the 2nd International Conference On Management, Economics, and Finance Proceeding. 28 -29 October 2013, Sabah.

Siraj, S. A. (2012). An empirical investigation into the accounting, accountability and effectiveness of WAQF management in the State Islamic Religious Councils (SIRCs) in Malaysia. Ph.D Thesis, Cardiff University.

Thorncroft, M. (1965). Principles of estate management, Estates Gazette Limited: London.

Zakaria, M., Hassan, M. S., \& Latiff, R. A. (2014). Pelaporan Wakaf di Malaysia: Mengenalpasti Keperluan Maklumat Pemegang Kepentingan. Paper presented at the Persidangan Kebangsaan Ekonomi Malaysia ke-9 (PERKEM ke-9), Terengganu,17 - 19 October 2014. 